\title{
The Impact of CEO Competence Heterogeneity and Investor Risk Appetite on Corporate Bond Yield- Take the Listed Companies of the Real Estate Industry as an Example
}

\author{
Han-Ting Wang* \\ CHINA-ASEAN International College, \\ Dhurakij Pundit University, Bangkok, Thailand
}

\author{
Sze-Ting Chen \\ CHINA-ASEAN International College, \\ Dhurakij Pundit University, Bangkok, Thailand
}

\begin{abstract}
The purpose of this paper is to propose a new integrated model that combines the concepts of risk and CEO competence. Risk is the deviation of the result caused by the different effects. Putting risk into the real capital market due to information asymmetry and imperfect capital market, investors must bear the investment-oriented risk while pursuing excess remuneration. The Chief Executive Officer (CEO), the core decision-maker, plays an important role in corporate bond yields, but the impact of CEO competence heterogeneity on corporate bond yield performance rarely indicates noticeable. A structural equation model and five-way interactions in moderated multiple regressions were used to test the hypotheses on a sample of 215 bond yields issued by 43 A-share listed companies in SSE and SZSE as a research sample in 2007-2017 and collected 473 sample data for 11 years in China. These results indicate that five indicators of the company's return on assets ROA, CEO relative salary, CEO education, CEO qualification and CEO holdings to measure the heterogeneity of CEO competence and the exploring of impact on corporate bond yields. It also considers the investor risk appetite factor and considers the macro factor GDP as the influencing factor to investigate the impact of investors as risk enthusiasts or risk aversion on corporate bond yields. The present study conceptualized the two influencing factors of CEO competence heterogeneity and investor risk preference, and it is expected to explore the impact of corporate bond yield. The study concluded that the company's return on assets ROA, CEO relative salary, CEO education, CEO holdings, and investor risk premium would significantly impact corporate bond yields. CEO qualifications and GDP make no significant impact on corporate bond yields. To the best of the knowledge, how A-share listed companies identify CEO competence heterogeneity to create organization performance, thereby promoting the development of risk and CEO competence heterogeneity of China, has not been analyzed in financial literature. Thus, the present study provides a significant contribution to the human capital literature, in which empirical research analyses the five-way interaction and demonstrates the empirical insights that may be used to study human capital. The findings reported in this study will encourage future researchers to employ a heterogeneity human capital perspective.
\end{abstract}

Keywords: CEO capability heterogeneity, investor risk appetite, bond yield, real estate industry, GDP

Received: 09 March 2020; Accepted: 17 May 2020; Published: 03 August 2020

\section{INTRODUCTION}

Strengthening relationship with CEO capability heterogeneity has become a crucial task for financial marketing because a strong CEO can lead to a better performance. Bond rolls, if frankly speaking, are not only the main means

\footnotetext{
${ }^{*}$ Correspondence concerning this article should be addressed to Han-Ting Wang, CHINA-ASEAN International College, Dhurakij Pundit University, Bangkok, Thailand. E-mail: 1215246839@qq.com

(C) 2020 The Author(s). Published by KKG Publications. This is an Open Access article distributed under a Creative Commons AttributionNonCommercial-NoDerivatives 4.0 International License.
} 
for companies to raise long-term capital, but also provide financing support for high-growth companies while helping emerge industries such as information technology that would have the financial strength for large-scale innovation. In addition, the funds raised by certain high-yield bonds are used for M\&A transactions such as leveraged buyouts, which strongly promote corporate $M \& A$, restructure activities, improve corporate governance structure, and improve corporate operating efficiency. It, on the other hand, can be seen from the abovementioned conditions that small changes in bond yields may lead to the resultthe company's huge capital allocation changes (Liu, Xiao, \& Xie, 2020).

The US high-yield bond market emerged in the late 1970s and early 1980s. The value of new bond issuances increased from US\$ 651 billion in 1996 to US\$ 100 billion in 2011, and the stock size reached US\$ 128.12 billion. The global stock of high-yield bonds approximately accounts for $60 \%$. The US high-yield bond issuance volume reached US\$ 222.6 billion in 2011. The development of the high-yield bond market represented by the United States has effectively promoted the following financial market prosperity and economic development and achieved the following effects: 1) to provide a stable source of funds for the development of small and medium-sized enterprises that were previously excluded from the corporate bond market and failed to reach the investment level; 2) to provide financing support for high-growth enterprises, so that emerging industries such as information technology would have the financial strength for large-scale innovation; 3) the funds raised by certain high-yield bonds are used for M\&A transactions such as leveraged buyouts, which strongly promote corporate M\&A, restructure activities, improve corporate governance structures, and improve corporate operating efficiency.

Moreover, the establishment of China's national debt market appears the beginning of the establishment and development of China's bond market and the beginning of financial market reform. On March 1987, China promulgated the "Interim Regulations on the Administration of Corporate Bonds." The regulations indicate that the state has begun to implement legalized centralized management of corporate bonds. In the second half of 1989, the State Council approved RMB 1.2 billion of local enterprise bonds, and bond issuance was completed as scheduled. From 1995 to 1996, Chinese corporate bonds entered into relatively stabilized development track. The issuance of corporate bonds nationwide reached to 38 billion yuan indicating an increase of $26.66 \%$ over 1997 . With the expansion of the inter-bank bond market, the over-the-counter bond market has gradually evolved into the dominantly-driving force in China's bond market. On the other hand, the promising development of the real estate industry is of great significance to the steady growth of China's economy. With the strengthening of the government's macro-control, especially the control of the real estate loan business by the banking industry and the increase in loan interest rates, the financing of real estate companies' investment projects appears more difficult along with the cost being increased, which has forced real estate companies to make major changes in financing methods-Bank loans have diversified into financing methods. Since the unbundling of Real Estate Company debt financing, corporate bonds have become an increasingly important financing channel for real estate companies (Czech \& Roberts-Sklar, 2019). However, due to China's mounting supervision in 2017, the proportion of real estate corporate bonds has sharply fallen, and bond issuance rates have continued to rise. Leading companies in listed real estate companies have always been embracing certain advantage. The domestic bond issuance rate of the top 20 real estate companies in 2017 is about $5.00 \%$, and the remaining listed real estate companies are about $5.80 \%$ (weighted average). As the interest rate gradually rises, the top 20 leading companies shrink the bond issuance. The gap between the scales of non-leading companies in 2015 has continued to expand; on the one hand, verifying that the leading companies are currently relatively abundant. Furthermore, this indicates that the financial costs of non-leading companies will continue to increase relatively in the future (Pereira, Cortez, \& Silva, 2019).

In this paper, we reviewing on previous research, it is relatively rare to focus on investor risk appetite for corporate bond yields, and whether the heterogeneity of CEO capabilities has the same significant effect on corporate bond yields as risk appetite. Plus, more research in the past had explored the senior management team rather than measuring the impact of CEO capability heterogeneity on corporate bond yields. Secondly, this study introduces the investor's risk appetite to see if its explanation increases. Investors will show different characteristics when they carry out investment activities. These characteristics can be divided into risk enthusiasts, risk neutrals and risk aversions. This article studies how investors' different risk appetite affects their investment behavior, and then how it affects corporate bond yields. It can enrich the research on the influencing factors of corporate bond yields. Furthermore, whether the heterogeneity of CEO capabilities will affect corporate bond yields? Is the impact positive or negative? Finally, do different investors' risk appetite affect corporate bond yields? Is it positive or negative?

The goal of this study is to compare CEO capability heterogeneity with investor risk appetite in terms of their dynamic effects on corporate bond yields so as to provide insightful implication for managing directors because the 
bond market is indispensable in the financial economy part, and rather than equities, companies may be more willing to choose to raise funds by issuing bonds at a lower financing cost. Most studies show that a good CEO has a significant impact on a company's operating performance and also plays an important role in certain investment decisions. Baik, Farber, and Lee (2011) studied the positive relationship between CEO capabilities and earnings forecasts, and found that CEO capabilities can increase the credibility of management forecasts. On the other hand, investors with different risk appetites will have different choices for investing in bonds. Therefore, investors' risk appetite serves also one of the critical factors that companies need to take into consideration as issuing bonds. Deng (2006) found that compared with developed countries, Chinese individual investors are more inclined to invest in risk-free assets when investing. Honggang (2012) analyzed the relationship between investor risk appetite, risk constraints and capital allocation, and used the VaR model to characterize investor risk appetite (Czech \& Roberts-Sklar, 2019).

This work contributes to the literature on the following perspectives. To begin with, listed real estate companies have strong industry representation. Thus, in-depth study of this industry cluster can fully reflect the entire real estate industry in market development, operation management, marketing, industry risk, and basic trends in development orientation. Alternatively, the information disclosure of real estate listed companies remains relatively complete and accurate. Through the scientific, fair, objective, and authoritative evaluation index system, evaluation methods and in-depth typical studies, the comprehensive strength of real estate listed companies can be evaluated as in-depth research. It is also being able to effectively promote the healthy competition and healthy development of real estate development enterprises and the entire industry, and has a strong guiding significance for the future development of the real estate market. In addition, since the reform and opening up, China's economy has ushered in an era of rapid development, and the subsequent market competition has become increasingly fierce. This paper combines the research on the heterogeneity of CEO capabilities and investor risk appetite, and explores its impact on corporate bond yields from another perspective. It is more helpful to grasp market conditions or avoid risks. Ultimately, in terms of the bond market, due to the relaxation of interbank and exchange market financing policies, real estate corporate bonds ushered in a spurt of development in 2015 and 2016. Through the study of the impact of bond yields, this article can better help companies to raise funds by issuing bonds and provide some references for investors to invest in bonds. At present, there is very little research on bond yields in China in terms of CEO capability heterogeneity. Most of the scholars' research objects are senior management teams. This study is not only a study of a certain characteristic of the CEO, but also integrates various indicators that affect the CEO's ability, and analyzes these indicators to measure the heterogeneity of the CEO's ability, and then studies the impact on bond yields. Then, this study also introduces the risk appetite of investors, because investors will show different characteristics when they carry out investment activities. These characteristics can be divided into risk enthusiasts, risk neutrals and risk aversions. This article studies how investors' different risk appetite affects their investment behavior, and then how it affects corporate bond yields. It can enrich the research on the influencing factors of corporate bond yields.

\section{LITERATURE REVIEW AND HYPOTHESES}

\section{China's Bond Market}

The establishment of China's national debt market refers to the beginning of the establishment and development of China's bond market and the beginning of financial market reform. Compared with Western countries, China's exposure to debt and bonds is relatively late. The People's Victory Discounted Public Debt is China's first bond issued in the 1950s after the founding of the People's Republic of China. In the early days of the founding of the PRC, the state requested the need for construction funds. At that time, the leadership was considered not advanced and the idea of wartime economy was used, that is, by mobilizing the patriotic enthusiasm of citizens, citizens were encouraged to actively purchase government bonds. Due to that fact that inflation was relatively high at that time, it was repaid in kind. By 1958, new government bonds were no longer issued, and local governments could issue local government bonds as needed. The local government's distribution was also terminated in 1962. After the reform and opening up, the state reissued bonds in 1981 to make up for the fiscal deficit caused by decentralization. The reason for this issuance was not because of economic difficulties, but because the state delegated power to enterprises in 1979 and 1980. As a result, fiscal revenue has fallen rapidly for two consecutive years. In order to expand the autonomy of enterprises, the state adopted a decentralized approach to state-owned enterprises. The approach is to distribute profits to workers as bonuses, welfare funds and enterprise development funds. With bonuses and benefits, workers are actively motivated to work. Enterprises have the funds for development, which increases the motivation for independent development. China's 
corporate bond market began to develop slowly since the state resumed issuing national bonds in 1981. On March 1987, the state promulgated and implemented the Interim Regulations on the Management of Corporate Bonds. This regulation marks that the state has begun to implement centralized management of corporate bonds. The interest rate of corporate bonds must not exceed $40 \%$ of bank deposits during the same period. At the second half of 1989, the State Council approved the scale of 1.2 billion yuan of local enterprise internal bonds, and bond issuance was completed as scheduled. In 1992, the State Council approved the issuance of a corporate bond issuance plan of 35 billion yuan.

Since 1992, there have been more and more ways of social fund raising, which have severely impacted the corporate bond market, especially the national bond market, and the issuance has not been extremely smooth. In addition, a large amount of bank funds, due to the chaotic capital market, were borrowed while funds for key national construction projects were insufficient. In July of the same year, the State Council decided to transfer most of the 1993 corporate bond issuance plan to new bank loans. From 1995 to 1997, Chinese corporate bonds entered a stable development track. The Chinese corporate bond market was initially formed and the market mechanism began to play a role. In 1997, it grew by $26.66 \%$. With the expansion of the interbank bond market, the OTC bond market has gradually evolved It is the leading force in China's bond market.

\section{Corporate Bond Yield}

Corporate bonds refer to marketable securities issued by listed companies in accordance with legal procedures and agreed to repay principal and interest within a certain period of time (Rufei, 2013). Qiang and Hengfu (2015) believe that corporate bonds and corporate bonds are fixed income securities based on corporate or corporate credit. They are an important channel for companies or companies to directly raise funds from the public, and they are also a risk comparison option for the public. The corporate bond yield is the ratio between the total annual output invested in corporate bonds and the total investment principal (Davit, 2019; Yikuan, 2006). Qiang and Hengfu (2015) believe that compared with China's bond market, foreign capital markets are more mature, and corporate bonds, as important basic securities, usually have higher issuance and holdings than national bonds and stocks. During the rapid development of China's financial market, the development of the corporate bond market has been relatively slow-moving. L. Li (2006) believes that government intervention can be also perceived as a crucially-significant factor toward China's corporate bond market, and its impact may cause distortion of corporate investment behavior. Therefore, this study considers that the corporate bond yield is the ratio of the total income obtained by investors when they make a purchase of corporate bonds to the total investment. In the first half of 2015, China's economic situation was not optimistic, and China faced many economic risks. By contrast, the real estate corporate bond market appears tremendously active. At the end of August 2015, the scale of issuance of real estate corporate bonds showed a blowout growth. The issued corporate bonds totaled 13.53.29 billion yuan. W. Jing and Yanming (2015) point out that relatively flexible issuance terms and high bond ratings can effectively reduce bond issuance rates. L. Li (2006) suggests that the corporate bond market is regarded as one of the consequential components of the financial market and is also exceedingly vital for the development of the entire Chinese financial market. For enterprises, a developed corporate bond market can bring a lot of convenience to enterprises and improve their ability to adapt to market changes.

\section{CEO Capability Heterogeneity}

Taylor (2010) proposed that CEO capability heterogeneity refers to the difference in the capabilities of the CEO in various aspects. In order to measure the differences between CEO capabilities, a research model was constructed for empirical analysis. The CEO is the top executive in a company who handles the day-to-day affairs of the company. Haixia (2017) believes that due to the current development of China's professional manager market system, So the CEO of a listed company is usually the chairman. Jianming (2014) has confidence in the fact that the CEO, as the company's top management, plays a very important role in the company's decision-making process. In China's more special corporate governance and management environment, CEOs have a significant influence on corporate strategic decisions. Hambrick and Mason (1984) proposed the Upper Echelons Theory, which is believed that strategic choices are caused by the interaction of multiple behavioral factors due to complex decision-making. However, as it is difficult to quantify variables such as cognitive orientation and values, Hambrick and Mason (1984) proposed observable variables such as age, education background, and professional Beijing as substitute variables. Heterogeneity of CEO capabilities may affect CEO substitution decisions. In order to make a reasonable CEO replacement decision, the board must properly evaluate the CEO's management capabilities and potential contribution to the company and the possibility of recruiting 
better people from the market. This study defines the CEO as the general manager of a company and is identified as the chairman without a general manager position.

\section{The Impact of Heterogeneity of CEO Capabilities on Bond Yields}

ROA (Baik et al., 2011; Rajgopal, Shevlin, \& Zamora, 2006) is also called return on assets. It is an indicator used to measure how much net profit is created per unit of assets. It measures the profit from every dollar of assets which would be the ratio of net profit to total assets, including operating assets and non-operating assets. For example, a company holding cash should include operating cash and surplus cash while cash in current assets in the traditional balance sheet is not Such a classification, such as the securities held by many companies or the investments of subsidiaries that are not included in the consolidated statement, are not operating assets, but all are included in the total assets.

Issuing bonds is a common form of corporate financing. If the financing is invested in the company's business and can bring new profits or expand the scale of the company. Corporate bonds are naturally beneficial to the company's development, so the issuance of corporate bonds will generally generate a positive impact on the company. For the company's CEO, choosing the right time to issue bonds is being deemed essentially critical. Full consideration must be given to the future expectations of interest rates. Issuing bonds is never being the same as issuing stocks. Bond repayment terms are generally longer. Although the capital cost of bond financing is lower than that of stock issuance, the procedures are relatively complicated. The requirements for enterprises themselves will then be stricter. Min and Dixing (2012) hold the firm point that traditional corporate finance theories mainly focus on the impact of market environment, corporate characteristics, and governance structure on investment and financing decisions, but a large number of empirical studies and actual evidence show that even these companies with similar factors. It also makes very different choices when making investment, mergers and acquisitions, and financing decisions. Based on this, some scholars began to pay attention to the impact of CEO heterogeneity on corporate financial decisions. Belief biases can cause differences between actual financing costs and managers' expectations. Heaton (2002) points out that optimistic managers will think that the market underestimates the value of the company and tends to use the company's internal funds because the cost of internal funds is often not affected by the manager's beliefs. In the same token, the cost of equity financing may be more easily miscalculated by the manager than the debt method. As the matter of fact, under the assumption that managers overestimate the expected return of the company. The results of corporate financing decisions are similar to the idea of superior financing, except that the possible hidden costs of different financing methods come from the manager's belief or the lack of information from investors. Malmendier, Tate, and Yan (2010) put confidence in the fact that bond investors will underestimate the payments they can get when a company defaults, bond financing is relatively large. But equity financing is a kind of real option, and the market that overestimates the risk of business operation will overvalue the enterprise value. Corporate financing decisions will prefer external equity financing, and least favor debt financing. Because it is difficult to separate the two managers' overconfidence and optimism from their belief biases, corporate financing decisions will also be affected by both factors.

Generally speaking, the improvement of the CEO's ability will bring better performance to the company. If the CEO's ability is not very different, the board has no reason to change the CEO until the CEO's performance drops toan unacceptably low level. In addition, some studies, such as Taylor (2010) and Cornelli, Kominek, and Ljungqvist (2013), have shown that the company's profitability has improved after the company replaced the CEO. Therefore, high CEO capability heterogeneity can improve the company's operating performance to a certain extent, thereby increasing the company's value. This article, therefore, makes the following assumptions:

H1: The higher the company's ROA, the higher the company's bond yield is.

Executive compensation has always been a difficult problem in corporate governance. CEO relative compensation (Chang, Dasgupta, \& Hilary, 2010; Neminno \& Gempes, 2018) is a widely used incentive in corporate governance. Generally speaking, high-performing or better-performing CEOs may substantially lead to higher salaries. Tao (2015) research found that $\mathrm{CEO}$ compensation has a significant positive impact on the company's future performance. Bebchuk, Cremers, and Peyer (2011) used CEO relative compensation as a measure of CEO power. From the perspective of the executive compensation index, state-controlled listed companies are lower than non-state-controlled listed companies. From the above mentioned points, it can be seen that the executives of state-controlled listed companies need to stimulate their vitality through orderly decentralization and effective incentives as well as self-discipline of executives. Generally speaking, more than half of the CEO's total compensation comes from stock and option grants from the 
previous year. According to a survey done by the data company Equilar to the Associated Press, in 2016, the CEOs of some large companies in the United States received an 8.5\% pay raise, and their 2016 salary, stock and other compensation combined averaged $\$ 11.5$ million. This is also the largest salary increase in the past three years. This increase also reflects how well the stocks of these companies performed in the year. After all, most of the CEO's compensation comes from stocks and other compensation, not their annual salary. Due to the special nature of the bond market, this article makes the following assumptions:

H2: The lower the CEO's salary, the higher the company's bond yield is.

Of the top 100 CEOs of Fortune 500 companies in 2018, 14 of them graduated from Ivy League University. Although some business leaders have a bachelor's degree, they have subsequently chosen to continue their studies, and most have subsequently graduated. According to a survey by a British domain company, relying on big data from the FTSE 100 Index and Fortune 100.

Harvard has created six CEOs in the United Kingdom and the United States. The University of Cambridge and the University of Oxford are tied for the highest ranking in the UK, with five CEOs each. Among the business school rankings, Harvard Business School is the most successful business school, with a total of nine CEOs who have studied at Harvard Business School. The University of Pennsylvania's Wharton School is second only to Harvard Business School with 6 graduates. Northwestern University's Kellogg School of Management has a total of 5 CEO graduates. From the above data, we can know that most successful CEOs still pay more attention to education. Generally, companies will pay more attention to the level of academic qualifications when recruiting talents. Although on the surface, it will not directly discriminate against academic qualifications, in practice, it will generally give priority to candidates with higher academic qualifications. In addition, diplomas are also very important in state-owned enterprises and institutions. Including some listed companies, their qualifications are one of the important references for salary increase and promotion when evaluating grades and titles. This article therefore makes the following assumptions:

H3: The higher the educational level of the company's CEO, the higher the company's bond yield is.

The CEO's human capital represents his work ability, work experience, and resume. The separation of management right and ownership in modern enterprises has made the status of managers in the enterprise unprecedentedly higher. The CEO, as the agent of the shareholders of the listed company, accepts the direct entrustment of the shareholders, and directly monitors the performance of the company's managers, and is at the core of the board of directors. The CEO is the company's most important operator representative. He is ultimately responsible for an organization's organization and strategy, planning, performance, and response to changes in the environment. It is considered the most influential person in the center of corporate power and controls and directs the organization's direction. Moving forward with goals that have an impact on the company's performance. On the one hand, the separation of the two rights provides the possibility for the optimal allocation of human capital and material capital, which is conducive to improving the economic benefits of enterprises, and on the other hand, it also causes the problem of principal-agent, which is not conducive to the improvement of economic benefits of enterprises. It is a pricing measure as well as an incentive measure to let the operator's human capital partially own the corporate equity in a certain way. The pricing of human capital of managers is to determine the value of human capital of managers. The pricing of human capital can be to determine the value of human capital in a certain period of time. It can also determine the value of human capital over the entire period. Among them, determining the value of human capital in a certain period of time is the issue of fixed compensation of human capital, and the value of human capital in all periods can be regarded as the sum of the present value of the value of human capital in each period. Relatively speaking, the issue of fixed human capital compensation is more realistic. This article therefore makes the following assumptions:

H4: The deeper the CEO's qualifications, the higher the companys bond yield are.

At present, China's capital market is in the period of institutional construction. The equity incentive system for executives of listed companies has been put on the agenda as the most important long-term incentive mechanism, and it has become important to promote the improvement of China's corporate governance structure and the sustainable and healthy development of the capital market and the national economy Mechanism. Equity incentives have a history of more than 50 years in mature foreign capital markets, but their development in China has been relatively slow, and they have not developed rapidly until the relevant legal systems have been improved in recent years. Due to the lack of effectiveness of the Chinese securities market, imperfect securities markets have weakened the correlation between 
stock prices and corporate performance. The governance structure of listed companies is imperfect, and the lack of independent institutions for the design and implementation of equity incentives affects the independence of their design and implementation. The lack of sound equity incentive evaluation system also affects the effectiveness of equity incentives. Due to the above reasons, the stock incentive system has not been fully implemented, which has affected its role in improving the performance of listed companies. Equity incentives for the CEO can largely guide the enthusiasm of his behavior, but this method may have a reverse effect on the CEO's compensation, that is, when the CEO is given more equity incentives, his compensation may be relatively reduced. However, it will have a positive effect on the company's performance and play a role in promoting the company's stock price, because bonds and stock prices have a negative correlation. This article therefore makes the following assumptions:

H5: The lower the company's CEO holdings, the higher the company's bond yield is.

\section{Investor Risk Appetite}

Due to the difference between an investor's own characteristics and his growing environment, each investor will react and judge differently to external information, thereby affecting the investor's investment behavior. Investors' risk appetite is that investors show different personal behaviors under the uncertainty of risk (Jingting, 2007). Investors' risk appetite can also be understood as their ability to tolerate risk (Chenxi, 2014). In traditional investment theories (CAPM, APT, etc.) all assume that investors are risk averse. That is, when the expected rate of return is the same, investors will choose a portfolio with less risk. However, this is not the case in reality. In China's securities market! During the average holding period of investors, the expected value of many investors' returns is not higher than the deterministic return of savings, and in many cases it is lower than the return of savings. Some investors have not withdrawn because of this. So it seems that it is not entirely true to assume that they are risk averse. Once an investor enters the market, the first problem that he faces is also the most critical one, which is what kind of portfolio to choose for investment. He needs an evaluation index of securities investment value that suits his risk appetite to compare various types of securities, and then decides his own investment portfolio.

\section{Impact of Investor Risk Appetite on Bond Yields}

Measuring risk appetite and Equity Risk Premium (ERP) has always been a difficult problem for A-share strategy research. Credit spread as a proxy variable for risk appetite is the classic "debt for stock" method, but interference factors are widespread. The relationship between changes in A-share market risk appetite and credit spreads is not stable. In the first half of 2016, global asset allocation showed a pattern of hedging and filling pits. Some oversold risky assets rebounded faster than expected, while the increase and growth rate of some safe-haven assets also showed strong offensiveness, making investors with high risk appetite begin to pay attention to the allocation of so-called "safe-haven assets." As a result, the transmission of risk appetite in various types of assets is smoother. This paper believes that the time for research on tandem asset allocation based on risk appetite research is ripe. The introduction of an asset allocation perspective of "same source debt" will help us to more accurately grasp the trend of overall market risk appetite. This report starts with the measurement of risk appetite based on large classes of assets. In the subsequent series of reports, we will systematically summarize the research methods of A-share risk appetite, and then analogize the risk appetite research to the large class. In terms of assets, in order to examine the rapid evolution of market characteristics of A-share investments and bond investments from a higher perspective. The impact coefficients of asset price fluctuations on risk appetite in global markets all show stock price fluctuations (exchange rate fluctuations). The characteristics of bond price fluctuations. The impact of price fluctuations in the Chinese market and commodity futures is far greater than the impact of exchange rate fluctuations. Globally, gold is a safe-haven asset, and its coefficient of influence on volatility is lower than that of U.S. Treasury bonds, but the coefficient of influence on domestic gold price fluctuations is even higher in stock indexes.

From the perspective of the United States, the stock market has fallen and the volatility of the stock market has increased; the overall yield of foreign bonds is in a downward cycle. The fluctuation of bond yields mainly comes from the decline in yields, the decline in bond yields and the rise in bond market volatility. Therefore, the increase in asset price volatility corresponds to a decline in stock prices and a decline in bond yields, an increase in risk aversion, and a decrease in risk appetite. The volatility of Chinese stock prices is similar to that of foreign countries. The difference is that domestic bond yields have increased significantly whether they are on the upside or downside. The increase in bond volatility may correspond to a decline in yield or an increase in yield. The profit model of China's bond market investors 
prefers trading capital gains rather than holding coupons. The bond market has strong trading game characteristics. The bond market has capital gains, and the funds remain in the bond market, and the risk appetite decreases; if the bond market falls, there is no capital gain, and funds may increase risk appetite in order to chase trading money. Turn to high-risk assets such as the stock market and commodities. China's capital market risk appetite has a "layered" feature, and the bond market's risk appetite for capital gains is at the lowest level. Banks and insurance-based asset allocation institutions are usually yield-oriented. If the bond market can provide sufficient yield, risk appetite will be significantly reduced; when the bond market yield is not sufficient to cover the target, risk appetite will be passive Promotion.

Risk premium is taken as a determining factor to consider on investment. The risk premium is the spread between the bond yield and the base rate. The credit risk of the debt-issuing company will cause investors to suffer certain losses. In order to ensure that investors are still willing to invest in high-risk bonds, the issuing entity needs to compensate investors for certain risks. Credit risk premium is generally considered as compensation for credit risk. From a stock perspective, due to the continued surge in the stock market in 2007, when it began to enter into a "national stock market," the cumulative money-making effect has greatly increased the risk appetite of the entire market, so everyone began to ignore the impact of performance and the impact of interest rates. Even the cooling of the policy could not stop the market trend. At the same time, the share of public funds increased rapidly, and reached its peak in the second and third quarters of 2007, which significantly boosted risk appetite. From the perspective of investment science, the risk premium can be regarded as the higher return required by investors for high investment risks. This article therefore makes the following assumptions:

H6: The higher the investor risk premium, the higher the company's bond yield is.

\section{RESEARCH METHODS}

\section{Sample Selection and Data Source}

This study selected corporate bonds issued by real estate companies listed on the Shanghai Stock Exchange and Shenzhen Stock Exchange. The sample-collecting period was started from 2007 to 2017 because this period covers the tsunami period. Samples of invalid and missing data were therefore deleted. The sample companies were selected from the list of the top 100 real estate listed companies listed in the "2018 China Real Estate Listed Companies Evaluation Study Report", and 43 sample companies remained after excluding companies listed in Hong Kong. In 11 years, 43 sample companies issued a total of 215 bonds, so there are 215 bond yield data. As the timing of issuing bonds is not regular, it is not a continuous data. Concerning the company's various indicators for a total of 11 years, a total of 473 sample data were collected. The data and other relevant data of the listed companies designed in this study are from the public information release of China Statistics Bureau and listed companies.

\section{Variable Measurement}

Explained variable: Corporate bond yield, which is a commonly used indicator for measuring corporate bond investment returns. Foreign literature studies the impact of corporate value and corporate size factors on bond yield spreads from a stock perspective, and the interaction of credit risk with default risk, stock market index, and credit default swaps on bond yield spreads. The research is more comprehensive, using more panel data and mostly static analysis. This study uses data on the yield to maturity of corporate bonds.

Explanatory variables: Heterogeneity of CEO capabilities, Heterogeneity of CEO capabilities include ROA, CEO compensation, CEO education, CEO age and CEO qualifications. ROA (Baik et al., 2011; Rajgopal et al., 2006), also known as return on assets, is an indicator used to measure how much net profit is generated per unit of assets. It measures the profit from every dollar of assets, which could be considered as the ratio of net profit to total assets. Studies such as Taylor (2010) and Cornelli et al. (2013) found that the company's profitability improved after the company replaced the CEO. Therefore, high CEO capability heterogeneity can improve the company's operating performance to a certain extent, thereby increasing the company's value (Chang et al., 2010).

Bebchuk et al. (2011) used CEO relative compensation as a measure of CEO power. Tao (2015) found through research that CEO compensation exerts a profoundly positive impact on the company's future performance. It is generally believed that the ability of a CEO is directly proportional to his salary. Therefore, it can be understood that the CEO can often get a higher price when his or her ability is greater. On the contrary, a lower salary level indicates that the CEO's ability is relatively low. The degree of CEO education and education can also reflect the 
difference in capabilities between CEOs to a certain extent. Ailing and Mingtao (2013) research found that the academic heterogeneity of the senior management team will affect the performance of the company's financial statements to a certain extent. Generally speaking, the higher the CEO's education, the stronger the ability to demonstrate than the lower education. Many research scholars use the educational level of the CEO ((Runtian, 2009); (Ailing \& Mingtao, 2013)) as a variable. Therefore, this study selects the level of CEO education and education as one of the indicators to measure the heterogeneity of CEO competence.

CEO qualifications are tremendously far-reaching for the position of CEO. A successful CEO must be proficient in applying the "flexible-to-flexible" strategy in the application for management of the enterprise, and must also have a demonstration of behavior along with a good ability to identify talents, a keen market insight, precise decision-making judgment, timely innovation and transformation power, and a high degree of core cohesion. Having these capabilities enables the CEO to create more performance for the company. This study uses CEO age as a measure of CEO qualifications.

The number of shares held by the CEO indicates how much the CEO owns the company's shares. In general, listed companies may adopt a system of equity incentives to stimulate the work enthusiasm of the CEO. Gao Hui (2006) believes that a single bonus and salary cannot effectively and positively affect the CEO, especially for the risk-biased $\mathrm{CEO}$, adding risk reward may help improve company performance. Accordingly, this article takes the number of CEO shares as a variable to measure the heterogeneity of CEO capabilities.

Risk premium is an influentially leading variable to measure risk appetite, and it is also the carrier of research on "risk appetite". Thence, this study introduces the concept of risk premium (ERP) to explain the change in "risk appetite" from a quantitative perspective. An increase in the risk premium means a reduction in risk appetite, and is a risk averser; a decrease in the risk premium means an increase in risk appetite, for a risk enthusiast.

Control variables: In addition, the control variables related to the characteristics of enterprises and bonds introduced in this study are: corporate financial leverage, company size, bond issuance period, and bond issuance amount.

In summary, the selection of variables in this article is summarized as follows:

Table 1 VARIABLES SCALE

\begin{tabular}{|c|c|c|c|}
\hline Explained Variable (Y) & Variable Name & Variable Description & Reference Source \\
\hline Corporate bond yield & Yield to Maturity (YTM) & $\begin{array}{l}\text { It is the internal rate of return on } \\
\text { investments in corporate bonds. }\end{array}$ & L. Li (2006) Yikuan (2006) \\
\hline \multirow[t]{5}{*}{$\begin{array}{l}\text { Explanatory variable }(\mathrm{X}) \text { : } \\
\text { CEO Ability heterogene- } \\
\text { ity (X1) }\end{array}$} & Return on Assets/ROA & $\begin{array}{l}\text { Reflects the strength of the } \\
\text { CEO's ability. POA refers to the } \\
\text { ratio of net profit to total assets. } \\
\text { It measures how much net profit } \\
\text { is created per unit of assets. }\end{array}$ & $\begin{array}{l}\text { Baik et al. (2011), Rajgopal et al. } \\
\text { (2006) }\end{array}$ \\
\hline & CEO Relative pay (WAGE) & $\begin{array}{l}\text { Refers to the salary that the CEO } \\
\text { can get. The higher the salary, } \\
\text { the stronger the ability of the } \\
\text { CEO. }\end{array}$ & $\begin{array}{l}\text { Chang et al. (2010), Bebchuk et } \\
\text { al. (2011), Tao (2015) }\end{array}$ \\
\hline & CEO Educational level (LOE) & $\begin{array}{l}\text { Refers to the education level of } \\
\text { the CEO, the higher the educa- } \\
\text { tion level, the higher the intelli- } \\
\text { gence level of the CEO }\end{array}$ & $\begin{array}{l}\text { Ailing and Mingtao (2013) } \\
\text { Runtian (2009) }\end{array}$ \\
\hline & CEO qualifications (AGE) & $\begin{array}{l}\text { Human capital is expressed by } \\
\text { the age of the CEO, the higher } \\
\text { the CEO s experience }\end{array}$ & $\begin{array}{l}\text { Weifeng (2016) Yujun and Bing } \\
\text { (2018) }\end{array}$ \\
\hline & No. of CEO shares (STOCK) & $\begin{array}{l}\text { The CEO's shares in the com- } \\
\text { pany, the more shares he holds, } \\
\text { the stronger the company's con- } \\
\text { trol }\end{array}$ & X. Jing (2012) Genwang (2013) \\
\hline
\end{tabular}


TABLE 1 CONTINUE

\begin{tabular}{|c|c|c|c|}
\hline Explained Variable (Y) & Variable Name & Variable Description & Reference Source \\
\hline Investor risk appetite (X2) & Risk premium (ERP) & $\begin{array}{l}\text { Refers to investors demanding } \\
\text { higher returns to offset greater } \\
\text { risks }\end{array}$ & $\begin{array}{l}\text { Hanna, Gutter, and Fan (1998) } \\
\text { Yi, Zhen, and Yaqian (2015) }\end{array}$ \\
\hline \multirow[t]{4}{*}{ Control variable } & $\begin{array}{l}\text { Financial leverage } \\
\text { (DFL) }\end{array}$ & $\begin{array}{l}\text { Refers to the leverage effect } \\
\text { of changes in common stock } \\
\text { earnings per share greater than } \\
\text { changes in EBIT due to debt }\end{array}$ & Q. Li and Jianping (2016) \\
\hline & Company size (SIZE) & $\begin{array}{l}\text { Use the total assets to measure } \\
\text { the size of the company }\end{array}$ & Kuhn (2012) Yihua (2006) \\
\hline & Bond maturity (BD) & $\begin{array}{l}\text { Refers to the time from the inter- } \\
\text { est calculation date of the bond } \\
\text { to the repayment of the principal } \\
\text { and interest date }\end{array}$ & $\begin{array}{l}\text { Zhan and Ping (2012) Xiangru, } \\
\text { Dixun, and Leiming (2012) }\end{array}$ \\
\hline & Bond issue amount (BI) & $\begin{array}{l}\text { Is the total face value of the } \\
\text { bonds issued. }\end{array}$ & (Xiaokun, 2009) \\
\hline
\end{tabular}

\section{Multiple Regression Analysis}

Based on the impact of CEO capability heterogeneity and investor risk appetite on bond yields, this study adopts a multiple regression model to explain what factors affect the changes in bond yields. The explanatory variables in the equation are CEO capability heterogeneity, Risk appetite and risk averter. This article builds a model in order to verify the assumptions proposed above, and the results are shown in the following figure:

$Y T M=\beta_{1}+\alpha_{1} R O A+\alpha_{2} W A G E+\alpha_{3} L O E+\alpha_{4} A G E+\alpha_{5} S T O C K+\alpha_{6} D F L+\alpha_{7} L n S I Z E+\alpha_{8} B D+\alpha_{9} B I+\varepsilon_{1}$ (1)

$$
\begin{aligned}
& Y T M=\beta_{2}+\alpha_{10} E R P++\alpha_{11} D F L+\alpha_{12} L n S I Z E+\alpha_{13} B D+\alpha_{14} B I+\varepsilon_{2} \\
& Y T M+\beta_{3}+\alpha_{16} R O A+\alpha_{17} W A G E+\alpha_{18} L O E+\alpha_{19} A G E+\alpha_{20} S T O C K \\
& +\alpha_{21} E R P+\alpha_{22} D F L+\alpha_{23} L n S I Z E+\alpha_{24} B D+\alpha_{25} B I+\varepsilon_{3}
\end{aligned}
$$

Among them, YTM is the yield of corporate bonds and bonds, ROA is the return on assets, WAGE is the relative salary of the CEO, LOE is the education level of the CEO, AGE is the age of the CEO, STOCK is the number of shares held by the CEO, ERP is the risk premium, and GDP is the fluctuation of the business cycle. Rate, DFL is the corporate financial leverage factor, SIZE is the size of the enterprise, BD is the bond maturity, BI is the bond issuance amount, $\beta 1-3$ is a constant, $\varepsilon 1-3$ is an error term, and $\alpha$ is a regression coefficient.

\section{RESULTS}

\section{Descriptive Statistical Analysis}

Descriptive statistical analysis sets to describe the relevant data of all variables in the survey, including the maximum, minimum, mean, and variance of the data. Hence, through the data collection of the dependent and independent variables described above, for the observation of the sample during the entire sample period (2007-2017), this study describes the median, mean, variance, and standard deviation of the study variables. Statistical Analysis. 
Table 2 DESCRIPTIVE STATISTICS OF EACH VARIABLE

\begin{tabular}{llllll}
\hline & Variable & Mean & Standard Error & Minimum & Maximum \\
\hline \multirow{2}{*}{ Explained variable Y } & YTM & 5.69 & 2.37 & 2.08 & 26.84 \\
Explanatory variable X & ROA & 3.05 & 2.25 & -8.59 & 9.97 \\
& WAGE & 6.20 & 0.50 & 4.68 & 7.08 \\
& LOE & 3.56 & 0.83 & 1 & 5 \\
& AGE & 54.77 & 6.125 & 41 & 68 \\
Control variable & STOCK & 0.42 & 0.40 & 0 & 1 \\
& ERP & 2.25 & 2.11 & -1.31 & 13.73 \\
& DEL & 2.44 & 0.70 & -19.18 & 14.05 \\
& LnSIZE & 14.55 & 1.78 & 6.17 & 18.57 \\
& BD & 4.87 & 1.79 & 1 & 15 \\
& BI & 17.02 & 13.41 & 0.7 & 90 \\
\hline
\end{tabular}

As can be seen from the above table, a total of 5 indicators of explanatory variables show a trend of normal distribution.

\section{Correlation Analysis}

Correlation analysis refers to the correlation analysis of factors between two or more variables, so as to measure the degree of correlation between the two variables. The elements of correlation need to have a certain connection or probability to perform correlation analysis.

Table 3 CORRELATION ANALYSIS OF VARIOUS VARIABLES

\begin{tabular}{|c|c|c|c|c|c|c|c|c|c|c|}
\hline & ROA & AGE & STOCK & WAGE & LOE & ERP & LnSIZE & DEL & $\mathrm{BD}$ & BI \\
\hline ROA & 1 & & & & & & & & & \\
\hline AGE & -0.153 & 1 & & & & & & & & \\
\hline STOCK & 0.037 & 0.033 & 1 & & & & & & & \\
\hline WAGE & 0.038 & 0.052 & 0.290 & 1 & & & & & & \\
\hline LOE & $0.456^{*}$ & -0.289 & 0.113 & 0.03 & 1 & & & & & \\
\hline ERP & $0.121 *$ & 0.070 & 0.031 & 0.070 & 0.066 & 1 & & & & \\
\hline LnSIZE & 0.124 & 0.006 & 0.019 & $0.504 *$ & 0.011 & 0.053 & 1 & & & \\
\hline DEL & -0.017 & 0.241 & -0.034 & 0.190 & -0.044 & 0.933 & $0.217 *$ & 1 & & \\
\hline $\mathrm{BD}$ & -0.112 & 0.108 & 0.021 & 0.019 & 0.277 & -0.032 & -0.137 & 0.231 & 1 & \\
\hline BI & 0.181 & 0.222 & 0.072 & $0.335^{*}$ & 0.145 & -0.115 & 0.134 & 0.085 & $0.307 *$ & 1 \\
\hline
\end{tabular}

Note: *** means $p<0.01 ; * *$ means $p<0.05 ; *$ means $p<0.1$

From the correlation analysis of the seven explanatory variables in the table above, the two indicators with the highest correlation are the ROA and the educational level of the CEO (LOE). The correlation between the two is 0.815 and 0.01 respectively. The overall correlation is average, so in the following research model, this article will take the method of independent variable regression to study the impact on corporate bond yields.

From the correlation analysis of the four variables of the control variable company size, corporate financial leverage, bond issuance term and bond issue amount, the strongest correlation is the bond issue amount and bond issue period of 0.307 , which is significant at the level of 0.05 . The lowest correlation is the bond issue amount and the company's financial leverage is 0.085 . 


\section{Independent Sample t Test}

For the hypothesis H1d of Model 1, the average age of the CEO according to the sample is 54.77 years. After taking the integer, this sample is divided into two groups, that is, the CEO is older than 55 years old and the younger is 55 years old or younger. Independent samples are grouped by $t$ test. The analysis results are shown in the following table.

Table 4 T TEST GROUP STATISTICS

\begin{tabular}{llllll}
\hline & Group & $N$ & Mean & Standard Deviation & Mean of Standard Error \\
\hline \multirow{3}{*}{ CEO age } & & & & & \\
& Senior & 23 & 59.30 & 3.509 & .732 \\
& Young age & 20 & 49.55 & 3.886 & .869 \\
\hline
\end{tabular}

Table 5 INDEPENDENT SAMPLE TEST

\begin{tabular}{|c|c|c|c|c|c|c|c|c|c|}
\hline & \multicolumn{5}{|c|}{ Levene Test } & \multicolumn{4}{|c|}{$T$-Test of Mean Variance } \\
\hline & $F$ & Sig. & $t$ & $d f$ & Sig & Mean & Standard & Error Value & Confidence Interval \\
\hline & & & & & & & Error Value & of Difference & Lower Limit Upper Limit \\
\hline Variance equal & .493 & .487 & 8.649 & 41 & .000 & 9.754 & 1.128 & 7.477 & 12.032 \\
\hline Variance not equal & & & 8.587 & 38.693 & .000 & 9.754 & 1.136 & 7.456 & 12.053 \\
\hline
\end{tabular}

According to above Levene test, results show $F=0.493, p=0.487>0.05$ From the Levene test results above, it can be known that $F=0.493, p=0.487$ is greater than 0.05 , which means that the variances are equal. The $t$ test of the mean equation is $t=-8.694$, and $p=0.000$ is far less than 0.05 , indicating that the bond yields of the senior and younger groups are statistical There are significant differences.

\section{Multiple Collinearity Test}

This study performed a VIF linear test on the data for each variable. From the results of the multicollinear VIF test, the maximum value is the CEO's relative salary (WAGE) of 1.285, less than 10 . The test result is 1.134, which is also lower than 10. The results show that there is no collinear relationship between the variables.

\section{Analysis of Factors Affecting Corporate Bond Yield}

Model 1

$Y T M=\beta_{1}+\alpha_{1} R O A+\alpha_{2} W A G E+\alpha_{3} L O E+\alpha_{4} A G E+\alpha_{5} S T O C K+\alpha_{6} D F L+\alpha_{7} L n S I Z E+\alpha_{8} B D+\alpha_{9} B I+\varepsilon_{1}$ 
Table 6 CEO CAPABILITY HETEROGENEITY REGRESSION ANALYSIS

\begin{tabular}{llll}
\hline Variable & Beta Value & $t$ Value & $p$ Value \\
\hline & & & \\
ROA & 0.219 & 2.446 & $0.016^{* *}$ \\
WAGE & -0.268 & -1.783 & $0.082^{*}$ \\
LOE & 0.255 & 1.686 & $0.099^{*}$ \\
AGE & -0.141 & -0.915 & 0.365 \\
STOCK & -0.299 & -2.003 & $0.052^{*}$ \\
DFL & 0.152 & 1.047 & 0.303 \\
LnSIZE & 0.047 & 0.329 & 0.744 \\
BD & -0.441 & -3.164 & $0.003^{* * *}$ \\
BI & -0.324 & -2.280 & $0.029^{* *}$ \\
$R^{2}$ & 0.819 & & \\
Adj $R^{2}$ & 0.760 & & \\
DW & 1.965 & & \\
& & & \\
\hline
\end{tabular}

Note:*** means $p<0.01 ; * *$ means $p<0.05, *$ means $p<0.1$

Table 7 ANOVA ANALYSIS

\begin{tabular}{lllllll}
\hline \multicolumn{1}{l}{ Model } & Sum of Squares & Df & Mean Square & $F$ & Sig. \\
\hline 1 & & & & & \\
& Regression & 45.774 & 9 & 5.086 & 24.643 & .000 \\
Residual & 63.497 & 33 & 1.924 & & \\
Toal & 109.272 & 42 & & & \\
& & & & & \\
\end{tabular}

From the regression results in Table 6 and Table 7, the return on assets, CEO relative salary, CEO education level, and CEO shareholding will affect the yield to maturity of the bond in the heterogeneity of CEO capabilities, and the age of the CEO will affect the bond yield. Yield to maturity has no effect, so it also validates the assumptions proposed in Chapter 3. H1, H2, H3, and $\mathrm{H} 5$ are all supported, and the assumptions made by $\mathrm{H} 4$ are not supported.

Model 2

$$
Y T M=\beta_{2}+\alpha_{10} E R P+\alpha_{11} \operatorname{LnGDP}+\alpha_{12} D F L+\alpha_{13} \operatorname{LnSIZE}+\alpha_{14} B D+\alpha_{15} B I+\varepsilon_{2}
$$


Table 8 REGRESSION ANALYSIS OF INVESTOR RISK APPETITE

\begin{tabular}{llll}
\hline Variable & Beta Value & $t$ Value & $p$ Value \\
\hline ERP & 0.869 & 5.399 & $0.001^{* * *}$ \\
DFL & -0.052 & -0.644 & 0.529 \\
LnSIZE & 0.139 & 1.547 & 0.143 \\
BD & -0.463 & -4.430 & $0.000^{* * *}$ \\
BI & -0.381 & -4.280 & $0.001^{* * *}$ \\
$R^{2}$ & 0.925 & & \\
Adj $R^{2}$ & 0.903 & & \\
DW & 1.765 &
\end{tabular}

Note: *** means $p<.01$; ** means $p<0.05$, * means $p<0.1$

Table 9 ANOVA TABLE

\begin{tabular}{llllll}
\hline Model & Sum of Squares & Df & Mean Square & $F$ & Sig. \\
\hline Regression & & 6 & & & \\
Residual & 58.534 & 15 & 0.756 & & \\
Total & 5.867 & 21 & & & \\
\hline
\end{tabular}

From the regression results in Table 8 and Table 9 above, there is a significant relationship between the risk premium and the yield to maturity of bonds in investor risk appetite. To that end, it is verified that the H6 is supported.

Model 3:

$$
\begin{aligned}
& Y T M+\beta_{3}+\alpha_{16} R O A+\alpha_{17} W A G E+\alpha_{18} L O E+\alpha_{19} A G E+\alpha_{20} S T O C K \\
& +\alpha_{21} E R P+\alpha_{22} L n G D P+\alpha_{23} D F L+\alpha_{24} L n S I Z E+\alpha_{25} B D+\alpha_{26} B I+\varepsilon_{3}
\end{aligned}
$$

Table 10 TOTAL REGRESSION ANALYSIS

\begin{tabular}{llll}
\hline Variable & Regression Coefficients & $t$ Vlaue & $p$ Value \\
\hline ROA & 0.387 & 2.446 & $0.023^{* *}$ \\
WAGE & -1.656 & -1.783 & $0.082^{*}$ \\
LOE & 0.356 & 1.81 & $0.083^{*}$ \\
AGE & 0.018 & 0.736 & 0.467 \\
STOCK & -0.902 & -1.800 & $0.051^{*}$ \\
ERP & 0.343 & 4.353 & $0.002^{* * *}$ \\
DFL & -0.045 & -0.728 & 0.635 \\
LnSIZE & -0.278 & -1.912 & $0.057^{*}$ \\
BD & -0.450 & -3.164 & $0.003 * * *$ \\
BI & -0.030 & -2.280 & $0.029 * *$ \\
$R^{2}$ & 0.875 & & \\
Adj $R^{2}$ & 0.843 & & \\
DW & 1.859 & & \\
\hline Note: $* * *$ means $p<0.01 ; * *$ means $p<0.05, *$ means $p<0.1$ &
\end{tabular}


Table 11 ANOVA TABLE

\begin{tabular}{llllll}
\hline Model & Sum of Squares & Df & Mean Square & $F$ & Sig. \\
\hline 3 & & & & & \\
Regression & 56.786 & 8 & 1.584 & 9.965 & 0.003 \\
Residual & 7.615 & 13 & 0.159 & & \\
$\quad$ Total & 64.401 & 21 & & & \\
\hline
\end{tabular}

From the overall regression results in the table above, the variables that have a significant relationship with the bond's yield to maturity are the return on assets, the relative salary of the CEO, the education level of the CEO, the number of shares held by the CEO, and the risk premium. There is no significant relationship between CEO age and GDP and bond maturity. Based on the comprehensive comparison of the above three models, the results of Model 1 and Model 2 are basically the same as those of Model 3.

\section{Robustness Test}

In order to ensure the effectiveness of the empirical model of real estate company bond yields, the heterogeneity of CEO capabilities and investor risk appetite, this paper uses the bond interest rate and the face value of the bonds as surrogate variables for testing. The test results are consistent with the analysis of the empirical results in this paper, which indicates that the research conclusions in this paper are more credible.

\section{DISCUSSION AND CONCLUSION}

This research paper comprehensively draws the following conclusions. First of all, the empirical results of the yield on assets and the yield to maturity of bonds are significantly correlated. ROA is an index used to measure how much net profit is created per unit of assets. From the empirical results, it can be concluded that the correlation between ROA and corporate bond yield indicates exceedingly weak. (Yuhua, 2016) found that the corporate bond financing rate and corporate performance showed a U-shaped relationship through the second regression. Within a certain range, the corporate performance and the scale of bond financing had an inverse effect; however, beyond this range, the corporate performance Will increase as bond financing rates increase. There is a negative correlation between corporate debt financing and corporate performance. Although the empirical results of this study validate Hypothesis 1, this hypothesis appears insufficient, so the empirical results of this paper only show a slight Positive correlation. Secondly, the CEO's relative compensation has a significant impact on corporate bond yields, but the empirical results show a negative correlation. It shows that corporate bond yields may decrease with the increase of CEO's relative compensation. As the most important human resource of an enterprise, the CEO exerts a decisive influence on the performance level of the enterprise. Companies usually give CEOs higher salaries because they work harder to improve corporate performance. At this time, the business risks faced by the enterprise are relatively small, so the financing cost of using bonds for financing will be reduced. Because the financing cost of issuing bonds will be less than the financing cost of issuing stocks, companies will be more inclined to issue bonds for financing. Because of their operating conditions, the coupon rate when issuing bonds will not be much higher than the bank interest rate, which may only The bank's fixed deposit rate is about $1 \%$ higher, so the bond's yield to maturity will be lower. Thirdly, the educational level of the CEO has a significant positive correlation with corporate bond yields. Education level is one of the important considerations when a company appoints a CEO. Although it does not appear to directly discriminate against academic qualifications, in practice, applicants with higher academic qualifications are generally given priority. The empirical results show that the higher the educational level of the CEO will have a positive impact on bond yields. Then, CEO qualifications have no significant effect on the yield to maturity of bonds. This article selects CEO age as a quantitative indicator of CEO qualifications, indicating that the richer the CEO s human capital does not necessarily mean the richer experience in the real estate industry, of course The other industries are also of reference significance, but the control of the property market is not very strong, so the correlation is not significant. After that, the number of CEO shares has a significant effect on the yield to maturity of bonds in the real estate industry, but the number of CEO shares has a negative correlation with the yield to maturity of bonds. Since the 1990s, with the deepening of people's understanding of financial products, the bond yield and the stock price yield have shown a relatively weak or even negative correlation, 
which means that when the company's stock price rises, the price of corporate bonds May show a downward trend. Conversely, when the stock market is unstable and the company's stock price falls, the price of bonds may be stable or even increase. Last but not least, the risk premium has a significant impact on corporate bond yields in the real estate industry and is positively correlated. This shows that due to the particularity of the real estate industry, more and more investors are willing to invest capital in real estate company bonds, which has further stimulated the growth of real estate company bond yields.

\section{Managerial Implications}

Aiming at the municipal analysis process and results studied in this paper, we can combine the current development of the real estate industry and put forward some suggestions for China's real estate industry to be developing stronger and better.

Reasonably issue bonds to achieve financing purposes. For real estate companies, because the real estate bond market started late, and China's bond market did not have a perfect system in the early days, compared to the issue of stock financing, the issue of bond financing has stricter requirements on the company's operating conditions, so Companies rarely choose to issue bonds to finance. However, with the continuous development of the Chinese economy in recent years, the real estate industry has also grown rapidly, and more and more real estate companies have also begun to choose to issue bonds for financing. Because compared to the company's issuance of shares, the financing cost is lower.

Developing better CEO incentive policies. In the real estate industry, the selection of CEOs must be strict, and at the same time, the training of talents must be emphasized. As the company's most senior manager, the CEO's role in the company's decision-making process is also extremely important. Heterogeneity of CEO capabilities may affect CEO substitution decisions. In order to make a reasonable CEO replacement decision, the board must properly evaluate the CEO's management capabilities and potential contribution to the company and the possibility of recruiting better people from the market.

When investing, investors can gather the actual situation, and more consideration can be used to invest funds in bond investment. Although the price of bonds will change as interest rates fluctuate, if the holders hold the bonds at maturity and do not consider interest reinvestment, then the total income they receive at maturity is determined and investors need to face The main risk is default risk. In the case of holding maturity, whether the economy is good or bad, investment returns can be basically guaranteed, so bonds are often said to be relatively low-risk investment products, and it can also be said to be a hedge against the risks of risk averse tool.

\section{Theoretical Implications}

This article studies the bond market of China's real estate industry. Because the Chinese bond market system was not particularly perfect a few years ago, and the real estate bond market started late, most of the bond sample data selected in this study are concentrated in 2015. Years later, and only selected the 43 A-share listed companies listed on the Shanghai Stock Exchange and Shenzhen Stock Exchange. There are no statistics on small real estate companies. May not reflect the overall situation of the real estate industry more comprehensively. In response to this situation, first of all, the problem of sample data can be studied more convincingly by expanding the sample company data. In addition, the statistics and research of data can be conducted after the stable development of China's real estate industry bond market for a period of time, which can better help companies issue bonds and make investment choices for investors.

The variables selected in this article include the company's ROA, the CEO's relative compensation, risk premium, and GDP. The variables regarding the heterogeneity of CEO capabilities are only valid for the appointment period of the CEOs of the sample companies selected in this sample period, and the CEO age will increase year by year, and the CEO may choose to continue his education or change the CEO Will cause the variable data to change. In addition to the influencing factors selected in this article, changes in corporate performance, stock prices, and yields, as well as changes in market interest rates, may affect the yield of corporate bonds. Therefore, in future research, these indicators can be used to analyze the influencing factors of bond yields in order to improve the influencing factors of bond yields in various aspects. 


\section{Limitations and Future Research Recommendations}

Although several theoretical and managerial implications are offered in this study, some limitations of the work and benefits for further research should be explicitly noted. First, the data used in this study were collected from the heterogeneity of the CEOs of 43 listed real estate companies, which does not completely represent the entire real estate industry. In the future, we can expand the sample data for further and more comprehensive research. Second, the investors' risk appetite is not always fixed and may be affected by many factors. When investors change their investment decisions due to external factors or personal reasons, their risk appetite will change. For this reason, the degree of in-depth analysis of influencing factors on corporate bond yields in this paper is insufficient to fully reflect the impact of heterogeneity of CEO capabilities and investor risk appetite on corporate bond yields. In addition, macroeconomic factors cannot be added to the analysis because of time limitation, but macroeconomic analysis remains meaningfully imperative in the field of securities investment. Investors must carefully invest in bonds in accordance with macroeconomic trends, so that bonds can better play their "avoidance" "Risk tool".

\section{REFERENCES}

Ailing, P., \& Mingtao, Y. (2013). An empirical study on the relationship between the characteristics of executive teams and financial performance in cultural enterprises. Guangdong Social Sciences, 84(5), 5-14.

Baik, B., Farber, D. B., \& Lee, S. (2011). CEO ability and management earnings forecasts. Contemporary Accounting Research, 28(5), 1645-1668. doi:https://doi.org/10.1111/j.1911-3846.2011.01091.x

Bebchuk, L. A., Cremers, K. M., \& Peyer, U. C. (2011). The CEO pay slice. Journal of Financial Economics, 102(1), 199-221. doi:https://doi.org/10.1016/j.jfineco.2011.05.006

Chang, Y. Y., Dasgupta, S., \& Hilary, G. (2010). CEO ability, pay, and firm performance. Management Science, 56(10), 1633-1652. doi:https://doi.org/10.1287/mnsc.1100.1205

Chenxi, S. (2014). The impact of investor risk appetite on venture investment decisions. Cooperative Economy and Science and Technology, 14(13), 78-79.

Cornelli, F., Kominek, Z., \& Ljungqvist, A. (2013). Monitoring managers: Does it matter? The Journal of Finance, 68(2), 431-481. doi:https://doi.org/10.1111/jofi.12004

Czech, R., \& Roberts-Sklar, M. (2019). Investor behaviour and reaching for yield: Evidence from the sterling corporate bond market. Financial Markets, Institutions \& Instruments, 28(5), 347-379. doi:https://doi.org/10.1111/ fmii.12122

Davit, G. (2019). Capital market development: Challenges and opportunities. International Journal of Business and Economic Affairs, 4(3), 109-115. doi:https://doi.org/10.24088/ijbea-2019-43001

Deng, K. (2006). Research on the risk appetite and asset selection of Chinese individual investors (Doctoral Dissertation). Jinan University, Guangzhou, China.

Genwang, X. (2013). Research on accounting issues of stock incentives for listed companies. Journal of Economic Research, 36.

Haixia, L. (2017). CEO power, risk taking and corporate growth: Based on empirical research of listed companies in China. Management Review, 29(10), 198-210.

Hambrick, D. C., \& Mason, P. A. (1984). Upper echelons: The organization as a reflection of its top managers. Academy of Management Review, 9(2), 193-206. doi:https://doi.org/10.5465/amr.1984.4277628

Hanna, S., Gutter, M., \& Fan, J. (1998). A theory based measure of risk tolerance. Proceedings of the Academy of Financial Services, 15, 10-21.

Heaton, J. B. (2002). Managerial optimism and corporate finance. Financial Management, 31, 33-45. doi:https:// doi.org/10.2307/3666221

Honggang, W. (2012). An empirical study of investor preference, risk constraints and asset allocation. North China Finance, 3, 6-10.

Jianming, Y. (2014). CEO, CFO background characteristics similarity and corporate earnings management behavior. Finance and Accounting Newsletter, 14(9), 51-53.

Jing, W., \& Yanming, R. (2015). Research on corporate bonds in the real estate industry. Financial Markets, 15(12), $89-90$.

Jing, X. (2012). CEO power, independent director and capital expenditure decision. Economic Issues, 4, 71-75.

Jingting, Z. (2007). Utility analysis of investor risk appetite. Friends of Accounting, , 7(3), 12-13. 
Kuhn, T. S. (2012). The structure of scientific revolutions. Chicago, IL: University of Chicago press.

Li, L. (2006). Mandatory guarantee requirements and investor positioning in the corporate bond market. Financial Research, 6(3), 67-75.

Li, Q., \& Jianping, Z. (2016). Characteristics of corporate leverage in cyclic industry: Based on the empirical study of Chinese a-share listed companies. Contemporary Finance, 377(4), 63-73.

Liu, C., Xiao, Z., \& Xie, H. (2020). Customer concentration, institutions, and corporate bond contracts. International Journal of Finance \& Economics, 25(1), 90-119. doi:https://doi.org/10.1002/ijfe.1731

Malmendier, U., Tate, G., \& Yan, J. (2010). Managerial beliefs and corporate financial policies (Tech. Rep.). Cambridge, MA: National Bureau of Economic Research.

Min, P., \& Dixing, Z. (2012). Comment on the frontier theory of corporate finance under the assumption of manager heterogeneity. Financial Review, 12(3).

Neminno, R. C., \& Gempes, G. P. (2018). The moderating effect of intellectual capital on the relationship between corporate reputation and knowledge sharing of commercial banks. Journal of Administrative and Business Studies, 4(3), 145-155. doi:https://doi.org/10.20474/jabs-4.3.3

Pereira, P., Cortez, M. C., \& Silva, F. (2019). Socially responsible investing and the performance of eurozone corporate bond portfolios. Corporate Social Responsibility and Environmental Management, 26(6), 1407-1422. doi:https://doi.org/10.1002/csr.1756

Qiang, G., \& Hengfu, Z. (2015). Comparative research on the secondary market pricing of corporate bonds and corporate bonds. Financial Research, 15(1), 84-100.

Rajgopal, S., Shevlin, T., \& Zamora, V. (2006). CEOs' outside employment opportunities and the lack of relative performance evaluation in compensation contracts. The Journal of Finance, 61(4), 1813-1844.

Rufei, Z. (2013). Corporate liquidity and risk premium: Based on empirical research in China. Investment Research, 13(1), 43-55.

Runtian, N. J. J. (2009). An empirical study on the relationships between CEO characteristics, R\&D intensity, and external environment. Science Research Management, 30(5), 178-186.

Tao, Z. (2015). Directors' compensation, CEO's compensation, and company's future performance: Supervision or collusion? Accounting Research, 94(8), 49-56.

Taylor, L. A. (2010). Why are CEOs rarely fired? evidence from structural estimation. The Journal of Finance, 65(6), 2051-2087.

Weifeng, X. (2016). CEO age and corporate risk-taking: Empirical evidence from listed companies. Accounting Newsletter, 11 .

Xiangru, C., Dixun, W., \& Leiming, F. (2012). Analysis of factors affecting the term of corporate bonds in China. Journal of Xi'an Jiaotong University, 2012(5), 26-31.

Xiaokun, Z. (2009). Research on the bond market of emerging enterprises in East Asia. Southwestern University of Finance and Economics Press.

Yi, L., Zhen, Y., \& Yaqian, Z. (2015). Why there is a difference in the subjective and objective risk appetite of investors: Micro-evidence from chfs. Southern Economy, 314(11), 19-38.

Yihua, Z. (2006). An empirical study on the relationship between company size and stock returns. Journal of Shanghai University of Finance, 6(2).

Yikuan, A. (2006). On the credit function of corporate bonds. Economic Research Reference, 6, 42-48.

Yuhua, C. (2016). Research on the relationship between bond financing and corporate performance of listed companies (Master's thesis). Dongfang University of Finance and Economics, Jiaxing, China.

Yujun, M., \& Bing, Y. (2018). Empirical research on CEO salary, CEO human capital, and corporate performance taking real estate listed companies as examples. Jiangsu Business Forum, 402(4), 98-102.

Zhan, L., \& Ping, C. (2012). Differentiation of corporate bond issuance and loan maturity: An empirical study based on the incremental method. Securities Market Herald, 2, 21-27. 